\title{
Mineralogy of Meteorites from the North-Eastern India: A Brief Review
}

\author{
Bhaskar J. Saikia1 ${ }^{*}$, Gopalakrishnarao Parthasarathy², Rashmi R. Borah ${ }^{3}$ \\ ${ }^{1}$ Department of Physics, Anandaram Dhekial Phookan College, Nagaon, India \\ ${ }^{2}$ National Geophysical Research Institute (CSIR-NGRI), Hyderabad, India \\ ${ }^{3}$ Department of Physics, Nowgong College, Nagaon, India \\ Email: *vaskar_r@rediffmail.com
}

How to cite this paper: Saikia, B.J., Parthasarathy, G. and Borah, R.R. (2017) Mineralogy of Meteorites from the North-Eastern India: A Brief Review. Geomaterials, 7, 83-95.

https://doi.org/10.4236/gm.2017.73007

Received: May 31, 2017

Accepted: July 24, 2017

Published: July 27, 2017

Copyright (c) 2017 by authors and Scientific Research Publishing Inc. This work is licensed under the Creative Commons Attribution International License (CC BY 4.0).

http://creativecommons.org/licenses/by/4.0/

\section{(c) (i) Open Access}

\begin{abstract}
We present a brief overview of meteorites from the north-eastern India, with a focus on falls, finds, and research developments. To date, out of a total 150 numbers of meteorites fall/find in India (in Meteoritical Bulletin Database), only six meteorites from north-eastern region have received official international recognition from the Nomenclature Committee of the Meteoritical Society. Among these six meteorites, 2 finds and 4 falls, including one ureilite, two $\mathrm{H}$ chondrites and three L chondrites. The first meteorite from north-eastern India (Assam L5, Find) was documented in 1846. After a lack of 153 years, the first fall (Sabrum LL6 chondrite) was documented in 1999. The most recent fall is Kamargaon (L6) chondrite in 2015. Intensively researched meteorites of this region are Goalpara and Dergaon. The reported most massive meteorite of north-eastern India is Mahadevpur (H4/5) chondrite, $70.5 \mathrm{~kg}$ of total known weight, and the rest are $<13 \mathrm{~kg}$ of total known weight. The researches on these meteorites from north-east India can be applied to the newly recovered meteorites to understand the astrophysical enigma.
\end{abstract}

\section{Keywords}

Meteorite, Mineralogy, North-East India

\section{Introduction}

Rocks of extraterrestrial origin that penetrate the atmosphere and reach the Earth's surface are called meteorites. Meteorites recovered following observed falls are called falls; those which cannot definitely be associated with observed falls are called finds [1]. The fall and find of a meteorite is quite rare. The meteorites are classified on the basis of their mineralogy, structure and chemical compositions [2] [3] [4]. The major classification of meteorites is: stony meteorites 
constituting $92.8 \%$ of all meteorites, stony iron meteorites constituting nearly $1.5 \%$ and iron meteorites with abundance of 5.7\%. The standard method for identifying meteorites is to compare the chemical composition of the sample with that of the meteoritic rock previously studied [5]. The explosive growth of meteorite inventory has been accompanied by a steady growth in the science of meteoritics, and associated fields of observational small body astronomy, cosmochemistry, and astrobiology. The study of meteorites has specific contributions to materials science, e.g., discovery of new minerals, a refinement of our picture of the evolution of the solar system [6] [7]. A multidisciplinary approach to the documentation and interpretation of a meteorite provides interesting opportunities to the understanding of diverse scientific fields (e.g. [8]). Meteorites provide the most substantial evidence of the chemical and physical makeup of asteroids. The broad objectives of the meteorite studies are to understand the chemical and isotopic composition of the "solar nebula" that evolved to form the solar system objects, formation of the solar system, various physicochemical processes involved to their time scales and the present state of the solar system, connection of solar system with stellar environment, evolution of terrestrial planets including Earth, and to explore the origin and evolution of life and the dynamical processes involved in the meteorite delivery to Earth.

The Meteoritical Bulletin database recorded fall/find of Indian meteorites since 1621 (Appendix Table A1) with two ancient impact craters at Dhala (1700 - $2100 \mathrm{Ma}$ ) and Lonar (52000 \pm 6000 a) of Madhya Pradesh and Maharashtra respectively. Meteorite studies in India have been initiated in late 1960s. During the journey of Indian meteorite studies, some major outcomes, e.g., scrupulous studies of isotope records in early solar system solids using secondary ion and noble gas mass spectrometry techniques at Physical Research Laboratory, which led to the identification of fossil records of short-lived nuclides of stellar origin in early solar system solids; identification of the short-lived nuclide ${ }^{26} \mathrm{Al}$ as the heat source for early melting of planetesimals, etc. The fall and find of meteorite recovery rate in the north-eastern region of India is very low, yet some very special finds have been recovered (e.g. Goalpara).

\section{Meteorites Fall/Find in North-East India}

Here is a quick chronological survey of all meteorites from north-east India, including some of the most extensively-researched examples, with emphasis on the subjects of research in this field. Table 1 represents the meteorites fall/find in north-east India.

The meteorite documentation era of north-eastern region of India was started with the documented meteorite Assam L5 (1846) by Silberrad [9]. It is worthwhile to mention that, out of 150 documented meteorites from India (to date), only six meteorites have been officially recognized by Nomenclature Committee of the Meteoritical Society from north-eastern region of India with various sizes and chemical classes. 
Table 1. List of meteorites fall/find in north-east India during last two centuries.

\begin{tabular}{ccccccc}
\hline Meteorite & Fall/Find & Year of Fall/Find & Weight $(\mathrm{kg})$ & Fragments & Type & References \\
\hline Assam & Find & 1846 & 2.7 & Three & L5 & {$[9]$} \\
Goalpara & Find & 1868 & 2.7 & Single & Ureilite & {$[9]$} \\
Sabrum & Fall & 30 April 1999 & 0.478 & Single & LL6 & {$[18]$} \\
Dergaon & Fall & 2 March 2001 & 12.5 & Multiple & H5 & {$[19]$} \\
Mahadevpur & Fall & 21 February 2007 & 70.5 & Multiple & H4/5 & {$[25]$} \\
Kamargaon & Fall & 13 November 2015 & 12.1 & Single & L6 & {$[31][32][33]$} \\
\hline
\end{tabular}

\section{Studies on these Meteorites}

Assam $\left(26^{\circ} 00^{\prime} \mathrm{N} ; 92^{\circ} 00^{\prime} \mathrm{E}\right)$ is the first documented meteorite "find" in Northeastern India. Total known weight of this meteorite was $2.7 \mathrm{~kg}$ in the form of three fragments, was recovered from Meghalaya in 1846 [9]. Assam is a fine representative of one of the most abundant meteorite classes L5 chondrite.

Goalpara $\left(26^{\circ} 10^{\prime} \mathrm{N}, 90^{\circ} 36^{\prime} \mathrm{E}\right)$ meteorite is "find" in 1868 , a stony meteorite belong to ureilite achondrite. In last few decades it has become arguably the mostresearched meteorite from north-east India. Ureilite-achondrite is a rare type of stony meteorite that has a unique mineralogical composition, which is very different from that of other stony meteorites. It has seen a level of research being described in various articles. The total known mass of this meteorite is $2.7 \mathrm{~kg}$ and it is the massive of all Indian ureilites. Goalpara was the most massive ureilites known before the recovery of the Kenna ureilite in 1972. Only three of this rare class has been documented from India, among them, except Goalpara, both Dyalpur (1872) and Lahrauli (1955) are fall. Ureilites contain slightly high amounts of trace elements like $\mathrm{Cr}, \mathrm{Mn}$ and $\mathrm{Zn}$, but the distribution of trace elements like zinc between different silicate mineral phases is not well known. Bulk zinc contents of the more heavily shocked ureilites are lower compared to the weakly shocked ureilites. The reason for the low levels of zinc in Goalpara olivines is not yet understood [10]. The Goalpara is one of the heavily shocked ureilites which contains lonsdaleite together with diamond (see [11]). Goalpura meteorite has been identified as a stony meteorite that lacks chondrules and originated on a differentiated parent body. The petrographic studies of Goodrich also indicate Goalpara experienced higher shock pressures and temperatures [12]. Presence of lonsdaleite and diamond in carbon grains of Goalpara ureilite was reported by many authors (e.g. [11] [13] [14]). Generally, lonsdaleite is not found weakly shocked ureilites. Nakamuta and Toh (2013) observed coarse-grained olivine and pigeonite with minor amounts of blade-like shaped carbon grains and mosaic texture of olivine and pyroxene crystals in Goalpara ureilite. The well crystallized graphite coexisted with olivine and pyroxene during igneous processes is converted to high-pressure diamond by impact (see [15] [16]), which suggests that the meteorite has been heavily shocked [17]. Other polymorphous of carbon (e.g. chaoite and graphite) are also found in Goalpara ureilite. The black, fine grained agglomerates, a few tenths of $1 \mathrm{~mm}$ in sized diamond in Goalpara and 
Dyalpur are formed under shock above $160 \mathrm{~kb}$. In Goalpara ureilite, diamonds are mainly cubic, with less than 10 percent hexagonal (see [11]). According to Hanneman et al, there is no evidence of hexagonal diamonds of terrestrial origin and also cubic diamond cannot be transformed into hexagonal under static or shocked pressure combined with temperature. Therefore, they conclude that the diamonds found in Goalpara ureilite were formed by impact shock in space from well crystallized graphite existing with the meteorite before impact [11].

Sabrum $\left(23^{\circ} 05^{\prime} \mathrm{N} ; 91^{\circ} 40^{\prime} \mathrm{E}\right)$ is one of the six Indian LL6 chondrites, among Segowlie (1853), Dhurmsala (1860), Manbhoom (1863), Bhawad (2002) and Sulagiri (2008) of this class. It is the first documented "fall" of this region. The total known weight of Sabrum is $478 \mathrm{~g}$. The major mineral composition of Sabrum is olivine $\left(\mathrm{Fa}_{31.4}\right)$, orthopyroxene $\left(\mathrm{Fs}_{25.1}, \mathrm{Wo}_{2.0}\right)$, clinopyroxene $\left(\mathrm{Wo}_{45} \mathrm{En}_{45.6} \mathrm{Fs}_{9.4}\right)$ and plagioclase $\left(\mathrm{An}_{10.6} \mathrm{Ab}_{83.6} \mathrm{Or}_{5.8}\right)$ [18]. This meteorite is belongs to $\mathrm{S} 4$ category with moderate shock features and the exposure age $24.8 \mathrm{Ma}$. The activities of most of the short-lived isotopes indicate the low galactic cosmic-ray fluxes over the orbital space of the meteoroid during the last few years prior to its fall. The observed cosmic-ray fluxes of Sabrum corresponding to the solar quiet period between cycles 22 and 23 appear to be anomalously low and require further investigation (see [18]).

Dergaon $\left(26^{\circ} 42^{\prime} \mathrm{N}, 93^{\circ} 51^{\prime} \mathrm{E}\right)$ is the fourth meteorite "fall" in north-east India (Figure 1). It is also an exhaustively studied meteorite of this region. A multiple fell of meteorite was observed on 2nd March, 2001, with a fireball accompanied by two land detonations. The largest fragment, weighing $10.3 \mathrm{~kg}$, was recovered in the village of Balidua, ten $\mathrm{km}$ west of Dergaon town. Additional fragments were recovered in the village of Koilaghat of weighing about $1.5 \mathrm{~kg}$ and two fragments, each of weighing about $1 \mathrm{~kg}$, were recovered in Majuli. The possibilities of other fragments fell in the Brahmaputra River channels cannot be ignored. The total known weight of this meteorite is $12.5 \mathrm{~kg}$. This fall is classified and documented as Dergaon H5 chondrite [19]. The detail focussed on integrated petrology, bulk chemistry, oxygen isotopes, noble gas and cosmic ray track density of Dergaon reported by Shukla et al. (see [20]). A cosmic ray exposure of 9.7 Ma for Dergaon is inferred from the cosmogenic noble gas records (see [20]). Dergaon is a classic example of $\mathrm{H}$ chondrite with high chondrulematrix ratio. The chondrules of Dergaon contains porphyritic olivine, porphyritic
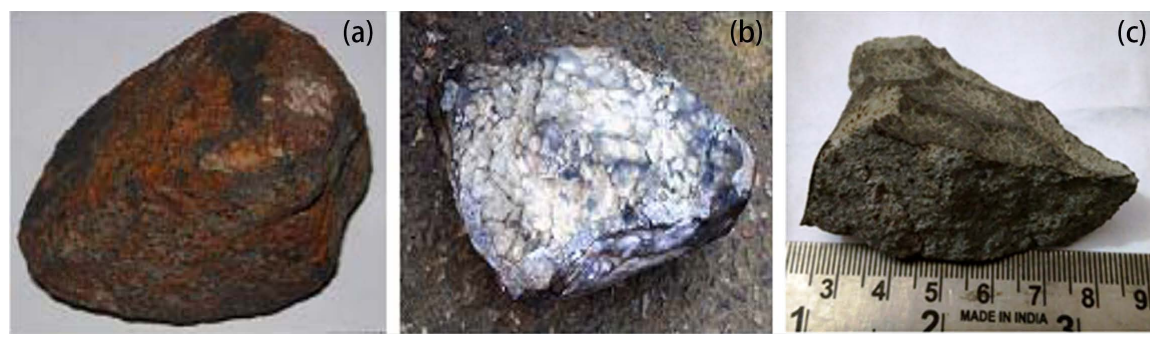

Figure 1. Photographs of some meteorites fell in North-eastern India. (a) Dergaon H5; (b) Mahadevpur H4/5; (c) Kamargaon L6. 
pyroxene, porphyritic olivine pyroxene, barred olivine, and barred pyroxene nearly $75 \%$ and about $25 \%$ non-porphyritic chondrules mainly radial pyroxene, cryptocrystalline, granular pyroxene and glassy ([21], see [22]). The lower value of $\mathrm{K}$ makes Dergaon notable among the $\mathrm{H}$ chondrites. The volatile elements such as $\mathrm{Zn}$ and Se are also absent in this meteorite. Besides olivine, orthopyroxene and clinopyroxene, kamacite and rare occurrences of taenite are also observed as exsolved lamellae in the metallic phases. Ray et al., has presented a reasonable explanation for bulk $\mathrm{K}$ depletion, interpretation of chondrule formation and shock-thermal history of the Dergaon. The vesicular texture in shockmelted feldspar and concomitant loss of $\mathrm{K}$ were attained during the post-shock decompression stage under low pressure (see [22]). The infrared stretching features of aliphatic hydrocarbon in Dergaon were reported by Saikia et al [23] [24]. The weathering of the meteorite sample cannot be overlooked for presence of these features. To date, Dergaon is one of the fifteen documented Indian H5 chondrites.

Mahadevpur $\left(27^{\circ} 40^{\prime} \mathrm{N}, 95^{\circ} 47^{\prime} \mathrm{E}\right)$ of total known weight $70.5 \mathrm{~kg}$, is the largest documented multiple fall of north-eastern India [25] [26]. The largest fragment, weighing $60 \mathrm{~kg}$ (Figure 1), was recovered in Pangari, about $40 \mathrm{~km}$ away from Mahadevpur. To date, only two Indian meteorites has classified of type H4/5. (i.e. Mahadevpur (2007) and Kendrapara (2003) chondrite). The mineralogical phases of olivine in Mahadevpur are: olivine $\left(\mathrm{Fo}_{80.8} \mathrm{Fa}_{19.3}\right)$, orthopyroxene $\left(\mathrm{En}_{81}\right.$ $\left.\mathrm{Fs}_{17} \mathrm{Wo}_{1}\right)$, and clinopyroxene $\left(\mathrm{En}_{58} \mathrm{Fs}_{8} \mathrm{Wo}_{35}\right)$ [27], albitic plagioclase $\left(\mathrm{Ab}_{87}\right.$ $\left.\mathrm{Or}_{3} \mathrm{An}_{10}\right)$, kamacite, taenite, apatite and rare chromite [25]. The matrix is a heterogeneous mixture of chondrule fragments, olivine, ortho-pyroxene and plagioclase. Chondrule sizes range from 250 to $1300 \mathrm{~mm}$. The Raman and infrared spectroscopic analysis of Mahadevpur reflects a partially polymerized silicate framework [27] [28]. Red luminescence characteristic features of olivine in Mahadevpur by Laser-induced fluorescence (LIF) are also reported by Dehingia and Baruah [29]. Olivine in chondrules and matrix do not show compositional variation, suggesting that Mahadevpur is an equilibrated $\mathrm{H}$-chondrite. The noble gas analyses suggest the exposure age of Mahadevpur is $6 \mathrm{Ma}$ (see [30]).

Kamargaon $\left(26^{\circ} 39^{\prime} 01^{\prime \prime} \mathrm{N} ; 93^{\circ} 46^{\prime} 02^{\prime \prime} \mathrm{E}\right)$ is the most recent fall of north-eastern India (Figure 1). A single stone fell from clear sky at the mustard oil cultivation field of the Bali-chapari village, near Kamargaon town in Golaghat District of Assam, India, on 13th November 2015 at 12:00 hrs (Local time) with fireball and a tremendous sound [31] [32]. The stone was fully covered with fusion crust and had well rounded edges and well developed regmaglypts (thumbprint like impressions) on its surface, that are formed by ablation of material from the surface as a meteor passes through the Earth's atmosphere. The strike of the meteorite makes a crater of $1.5 \mathrm{ft}$ diameter and penetrated the ground $3 \mathrm{ft}$ in depth. A single piece of meteorite of weight $12.095 \mathrm{~kg}$ is recovered and preserved under the custodian of the local police station. The fusion crust (about $1 \mathrm{~mm}$ of thickness) and the regmaglypths are clearly visible on the surface of Kamargaon meteorite. The olivine composition is estimated to Fo: $78.98 \mathrm{~mol} \%$; Fa: $20.80 \mathrm{~mol} \mathrm{\%}$ and 
Tp: $0.88 \mathrm{~mol} \%$. The bulk chemical composition and mineralogical data indicates that the Kamargaon meteorite is an L6 chondrite. In Kamargaon, ${ }^{22} \mathrm{Na} /{ }^{26} \mathrm{Al}$ activities ratio is lower than expected values for an $\mathrm{L}$ chondrite fall during the declining stage of solar cycle 24 [33].

\section{Conclusion}

All meteorites from north-eastern India were belongs to ordinary chondrites except Goalpara, which is stony achondrite. The studies of meteoritic olivine of these meteorites have been reported by many authors (e.g. [18] [34] [35] [36] [37]). The carbon polymorphous hexagonal diamond is usually formed in static and shock high pressure. The presence of diamond in Goalpara reflects this phase of temperature and pressure condition under which these diamonds are formed. The crystalline graphite is the main source of the meteoritic diamonds in Goalpara. Presence of nanodiamonds in Dergaon and Mahadevpur is also reported by Saikia et al. (see [38]). This finding has important implications concerning the origin of meteoritic diamonds. As the meteorites from north-east India are most common type chondrites, they originate from debris of the solar nebula (e.g. [7] [39]). Due to their unique origin, these chondrites are also regarded as the sole witness for the formation of the early solar system. For example, Dergaon chondrite reports several significant observations that help to understand both nebular and asteroidal processes (e.g. [22]). Meteorites still hold many secrets about our earth and other solar system bodies that are yet to be deciphered. The researches on the meteorites from north-east India will undeniably contribute to the understanding and demystify these secrets.

\section{Acknowledgements}

This paper is dedicated to $72^{\text {nd }}$ Birthday of Professor N.C. Sarmah, Department of Physics, Dibrugarh University, Dibrugarh. We are grateful to Professor N. Bhandari of Physical Research Laboratory, Ahmedabad for motivation and mentoring. G.P. thanks PLANEX, Physical Research Laboratory for funding.

\section{References}

[1] Krot, A.N., Keil, K., Goodrich, C.A., Scott, E.R.D. and Weisberg, M.K., (2005) Classification of Meteorites. In: Davis, A.M., Ed., Meteorites, Comets, and Planets. Treatise on Geochemistry, Elsevier-Pergamon, Oxford, 84-128.

[2] Larimer, J.W. (1971) Composition of the Earth: Chondritic or Achondritic? Geochimica et Cosmochimica Acta, 35,769-786.

https://doi.org/10.1016/0016-7037(71)90125-6

[3] Oura, Y., Ebihara, M., Yoneda, S. and Nakamura, N. (2002) Chemical Composition of the Kobe Meteorite; Neutron-Induced Prompt Gamma Ray Analysis Study. Geochemical Journal, 36, 298-307. https://doi.org/10.2343/geochemj.36.295

[4] Randa, Z., Kucera, J. and Soukal, L. (2003) Elemental Characterization of the New Czech Meteorite "Moravka" by Neutron and Photon Activation Analysis. Journal of Radioanalytical and Nuclear Chemistry, 257, 275-283.

https://doi.org/10.1023/A:1024767309558 
[5] Nair, A.G.C., Acharya, R., Sudarshan, K., Gangotra, S., Reddy, A.V.R., Manohar, S.B. and Goswami, A. (2003) Development of an Internal Mono Standard INAA Method Based on in situ Detection Efficiency for Analysis of Large and Non-Standard Geometry Samples. Analytical Chemistry, 75, 4868-4874. https://doi.org/10.1021/ac034457d

[6] McSween, H.Y. (1999) Meteorites and Their Parent Bodies. Cambridge University Press, Cambridge.

[7] Hutchison, R. (2004) Meteorites: A Petrologic, Chemical and Isotopic Synthesis. Cambridge University Press, Cambridge.

[8] Brown, P.G., Hildebrand, A.R., Zolensky, M.E., Grady, M., Clayton, R.N., Mayeda, T.K., Tagliaferri, E., Spalding, R., MacRae, N.D., Hoffman, E.L., Mittlefehldt, D.W., Wacker, J.F., Bird, J.A., Campbell, M.D., Carpenter, R., Gingerich, H., Glatiotis, M., Greiner, E., Mazur, M.J., McCausland, P.J., Plotkin, H. and Mazur, T.R. (2000) The Fall, Recovery, Orbit, and Composition of the Tagish Lake Meteorite: A New Type of Carbonaceous Chondrite. Science, 290, 320-325. https://doi.org/10.1126/science.290.5490.320

[9] Silberrad, C.A. (1932) List of Indian Meteorites. 290-304. https://doi.org/10.1180/minmag.1932.023.139.05

[10] Wasson, J.T., Chou, C.L., Bild, R.W. and Baedecker, P.A. (1976) Classification of an Elemental Fractionation among Ureilites. Geochimica et Cosmochimica Acta, 40, 1449-1450. https://doi.org/10.1016/0016-7037(76)90081-8

[11] Hanneman, R.E., Strong, H.M. and Bundy, F.P. (1967) Hexagonal Diamonds in Meteorites: Implications. Science, 155, 995-997. https://doi.org/10.1126/science.155.3765.995

[12] Goodrich, C.A. (1992) Ureilites: A Critical Review. Meteoritics \& Planetary Science, 27, 327-352. https://doi.org/10.1111/j.1945-5100.1992.tb00215.x

[13] Bundy, F.P. and Kasper, J.S. (1967) Hexagonal Diamond-A New Form of Carbon. The Journal of Chemical Physics, 46, 3437-3446. https://doi.org/10.1063/1.1841236

[14] Frondel, C. and Marvin, U.B. (1967) Lonsdaleite, a Hexagonal Polymorph of Diamond. Nature, 214, 587-589. https://doi.org/10.1038/214587a0

[15] Goodrich, C.A., Scott, E.R.D. and Fioretti, A.M. (2004) Ureilitic Breccias: Clues to the Petrologic Structure and Impact Disruption of the Ureilite Parent Asteroid. Chemie der Erde-Geochemistry, 64, 283-327.

[16] Nakamuta, Y. and Aoki, Y. (2000) Mineralogical Evidence for the Origin of Diamond in Ureilites. Meteoritics \& Planetary Science, 35, 487-493. https://doi.org/10.1111/j.1945-5100.2000.tb01430.x

[17] Nakamuta, Y. and Toh, S. (2013) Transformation of Graphite to Lonsdaleite and Diamond in Goalpara Ureilite Directly Observed by TEM. American Mineralogist, 98, 574-581. https://doi.org/10.2138/am.2013.4341

[18] Ghosh, S., Murty, S.V.S., Shukla, P.N., Shukla, A.D., Mahajan, R.R., Bhandari, N., Pant, N.C., Ghosh, J.B. and Shome, S. (2002) Fall, Classification and Cosmogenic Records of the Sabrum (LL6) Chondrite. Meteoritics \& Planetary Science, 37, 439448. https://doi.org/10.1111/j.1945-5100.2002.tb00826.x

[19] Grossman, J.N. and Zipfel, J. (2001) The Meteoritical Bulletin, No. 85, 2001 September. Meteritics \& Planetary Science, 36, A293-A322. https://doi.org/10.1111/j.1945-5100.2001.tb01542.x

[20] Shukla, P.N., Shukla, A.D., Rai, V.K., Murthy, S.V.S., Bhandari, N., Goswami, J.N., Mazumder, A.C., Phukon, K., Duorah, K., Greenwood, R.E. and Franchi, I.A. (2005) The Dergaon (H5) Chondrite: Fall, Classification, Petrological and Chemical 
Characteristics, Cosmogenic Effects, and Noble Gas Records. Meteoritics \& Planetary Science, 40, 627-637. https://doi.org/10.1111/j.1945-5100.2005.tb00967.x

[21] Wasson, J.T., Krot, A.N., Lee, M.S. and Rubin, A.E. (1995) Compound Chondrules. Geochimica et Cosmochimica Acta, 59, 1847-1869.

[22] Ray, D., et al. (2016) Insights into Chondrule Formation Process and Shock-Thermal History of the Dergaon Chondrite (H4-5). Geoscience Frontiers, 8, 413-423.

[23] Saikia, B.J., Parthasarathy, G. and Sarmah, N.C. (2009) Fourier Transform Infrared Spectroscopic Characterization of Dergaon H5 Chondrite: Evidence of Aliphatic Organic Compound. Nature and Science, 7, 45-51.

[24] Saikia, B.J., Parthasarathy, G., Sarmah, N.C. and Baruah, G.D. (2009) Organic Compounds in H5 Meteorite: Spectroscopic Investigation of Dergaon H5 Chondrite. Geochimica et Cosmochimica Acta, 71, 867.

[25] Weisberg, M.K., Smith, C., Benedix, G., Foloco, L., Righter, K., Zipfel, J., Yamaguchi, A. and Chennaouiaoudjehane, H. (2008) The Meteoritical Bulletin, No. 94. September 2008. Meteoritics \& Planetary Science, 43, 1551-1588. https://doi.org/10.1111/j.1945-5100.2008.tb01027.x

[26] Saikia, B.J. and Parthasarathy, G. (2009) Spectroscopic Investigation of Mahadevpur H4/5 Ordinary Chondrite. Geochimica et Cosmochimica Acta, 73, 1144.

[27] Saikia, B.J., Parthasarathy, G. and Sarmah, N.C. (2009) Spectroscopic Characterization of Olivine $\left[(\mathrm{Fe}, \mathrm{Mg})_{2} \mathrm{SiO}_{4}\right]$ in Mahadevpur H4/5 Ordinary Chondrite. Journal of American Science, 5, 71-78.

[28] Saikia, B.J., Parthasarathy, G., Borah, R.R. and Borthakur, R. (2016) Raman spectroscopic Study of Dergaon H5 and Mahadevpur H4/5 Chondrite. 47 th Lunar and Planetary Science Conference, No. 1799.

[29] Dehingia, N. and Baruah, G.D. (2010) Extended Red Emission in Mahadevpur (Namsai) Meteorite. Spectroscopy Letters, 43, 144-147. https://doi.org/10.1080/00387010903261198

[30] Murty, S.V.S., Mahajan, R.R., Shukla, A.D., Mazumdar, A.C., Shukla, P.N., Durga Peasad, K., Rai, V.K., Panda, D., Ghevaria, Z.G. and Goswami, J.N. (2009) Jodia (L5) and Mahadevpur (H4/5): Twp Recent Ordinary Chondrites Falls in India. 72nd Annual Meteoritical Society Meeting, No. 5058.

[31] Goswami, T.K., Ray, D., Sarmah, R.K., Goswami, U., Bhattacharyya, P., Majumdar, D., Bezbaruah, D. and Borgohain, P. (2016) Meteorite Fall at Komargaon, Assam, India. Current Science, 110, 1894-1895.

[32] Saikia, B.J., Parthasarathy, G. and Borah, R.R. (2017) Raman Spectroscopy of Kamargaon L6 Ordinary Chondrite. 48th Lunar and Planetary Science Conference, No. 1979.

[33] Rosén, A.V., Sivers, M.V., Hofmann, B.A., Schumann, M. and Pathak, D. (2016) Cosmogenic Radionuclides in the Komar Gaon Meteorite Measured in a New LowBackground Gamma-Ray Spectrometry Facility, GeMSE. 79th Annual Meeting of the Meteoritical Society, No. 6398.

[34] Bhattacharyya, S., Gohainbarua, A., Knowar, R., Changmai, R. and Baruah, G.D. (2004) Nature of the Emission Band of Dergaon Meteorite in the Region 5700 6700 Å. Pramana, 62, 1299-1301. https://doi.org/10.1007/BF02704442

[35] Gohainbarua, A., Barua, B.P., Bhattachyya, S. and Baruah, G.D. (2003) Spectroscopic Investigation of Dergaon Meteorite with Reference to $10 \mu \mathrm{m}$ and $20 \mu \mathrm{m}$ Bands. Pramana, 60, 47-52. https://doi.org/10.1007/BF02705067

[36] Saikia, B.J. and Parthasarathy, G. (2008) Spectroscopy of Dergaon Meteorite. Geochimica et Cosmochimica Acta, 72, 818. 
[37] Saikia, B.J., Parthasarathy, G. and Borah, R.R. (2011) Spectroscopic Characterization of Olivine Due to Fe/Mg in Dergaon Chondrite. Mineralogical Magazine, 75, 1780 .

[38] Saikia, B.J., Parthasarathy, G. and Borah, R.R. (2017) Nanodiamonds and Silicate Minerals in Ordinary Chondrites as Determined by Micro-Raman Spectroscopy. Meteoritics \& Planetary Science, 52, 1146-1154. https://doi.org/10.1111/maps.12850

[39] Zanda, B. (2004) Chondrules. Earth and Planetary Science Letters, 224, 1-17. 


\section{Appendix}

Table A1. List of meteorites from India (https://www.lpi.usra.edu/meteor/index.php accessed on 24.04.2017).

\begin{tabular}{|c|c|c|c|c|}
\hline & Year & Place of Fall/Find & Type & Mass \\
\hline Jalandhar & 1621 & Punjab, India & Iron & $1967 \mathrm{~g}$ \\
\hline Benares (a) & 1798 & Uttar Pradesh, India & LL4 & $3.7 \mathrm{~kg}$ \\
\hline Benares (b) & -- & Uttar Pradesh, India & Iron & -- \\
\hline Moradabad & 1808 & Uttar Pradesh, India & L6 & $70 \mathrm{~g}$ \\
\hline Punganaru & 1811 & Andhra Pradesh, India & Stone-unclassified & $100 \mathrm{~g}$ \\
\hline Chail & 1814 & Uttar Pradesh, India & H6 & $0.5 \mathrm{~g}$ \\
\hline Gurram Konda & 1814 & Andhra Pradesh, India & L6 & $28 \mathrm{~g}$ \\
\hline Durala & 1815 & Punjab, India & L6 & $13.2 \mathrm{~kg}$ \\
\hline Futtehpur & 1822 & Uttar Pradesh, India & L6 & $4 \mathrm{~kg}$ \\
\hline Kadonah & 1822 & Uttar Pradesh, India & H6 & $89 \mathrm{~g}$ \\
\hline Umbala & 1822 & Punjab, India & LL5 & $100 \mathrm{~g}$ \\
\hline Oriang & 1825 & Rajasthan, India & Doubtful meteorite & -- \\
\hline Mhow & 1827 & Uttar Pradesh, India & L6 & $350 \mathrm{~g}$ \\
\hline Kandahar (India) & 1833 & India & Doubtful stone & -- \\
\hline Charwallas & 1834 & Haryana, India & H6 & $12 \mathrm{~kg}$ \\
\hline Akbarpur & 1838 & Uttar Pradesh, India & $\mathrm{H} 4$ & $1800 \mathrm{~g}$ \\
\hline Chandakapur & 1838 & Maharashtra, India & L5 & $8.8 \mathrm{~kg}$ \\
\hline Kaee & 1838 & Uttar Pradesh, India & H5 & $230 \mathrm{~g}$ \\
\hline Myhee Caunta & 1842 & Gujarat, India & OC & -- \\
\hline Manegaon & 1843 & Maharashtra, India & Diogenite & $50 \mathrm{~g}$ \\
\hline Assam $^{* *}$ & 1846 & Meghalaya, India & L5 & $2.7 \mathrm{~kg}$ \\
\hline Singhur & 1847 & Maharashtra, India & Pallasite? & $14.18 \mathrm{~kg}$ \\
\hline Dharwar & 1848 & Karnataka, India & OC & $1800 \mathrm{~g}$ \\
\hline Shalka & 1850 & West Bengal, India & Diogenite & $4 \mathrm{~kg}$ \\
\hline Bustee & 1852 & Uttar Pradesh, India & Aubrite & $1500 \mathrm{~g}$ \\
\hline Yatoor & 1852 & Andhra Pradesh, India & H5 & $13.6 \mathrm{~kg}$ \\
\hline Segowlie & 1853 & Bihar, India & LL6 & $6.93 \mathrm{~kg}$ \\
\hline Sabetmahet & 1855 & Uttar Pradesh, India & H5 & $1250 \mathrm{~g}$ \\
\hline Parnallee & 1857 & Tamil Nadu, India & LL3.6 & $77.6 \mathrm{~kg}$ \\
\hline Dhurmsala & 1860 & Himachal Pradesh, India & LL6 & $32 \mathrm{~kg}$ \\
\hline Kheragur & 1860 & Uttar Pradesh, India & L6 & $450 \mathrm{~g}$ \\
\hline Kusiali & 1860 & Uttar Pradesh, India & L6 & $5 \mathrm{~g}$ \\
\hline Butsura & 1861 & Bihar, India & H6 & $29 \mathrm{~kg}$ \\
\hline Meerut & 1861 & Uttar Pradesh, India & H5 & $22 \mathrm{~g}$ \\
\hline Manbhoom & 1863 & West Bengal, India & LL6 & $1700 \mathrm{~g}$ \\
\hline
\end{tabular}




\section{Continued}

\begin{tabular}{|c|c|c|c|c|}
\hline Pulsora & 1863 & Madhya Pradesh, India & H5 & $560 \mathrm{~g}$ \\
\hline Bheenwal & 1865 & Rajasthan, India & Doubtful stone & $1470 \mathrm{~g}$ \\
\hline Muddoor & 1865 & Karnataka, India & L5 & $4.4 \mathrm{~kg}$ \\
\hline Shergotty & 1865 & Bihar, India & Martian (shergottite) & $5 \mathrm{~kg}$ \\
\hline Supuhee & 1865 & Uttar Pradesh, India & H6 & $7.24 \mathrm{~kg}$ \\
\hline Jamkheir & 1866 & Maharashtra, India & H6 & $22 \mathrm{~g}$ \\
\hline Pokhra & 1866 & Uttar Pradesh, India & H5 & $350 \mathrm{~g}$ \\
\hline Udipi & 1866 & Karnataka, India & H5 & $3.6 \mathrm{~kg}$ \\
\hline Khetri & 1867 & Rajasthan, India & H6 & $100 \mathrm{~g}$ \\
\hline Goalpara $^{* *}$ & 1868 & Assam, India & Ureilite & $2.7 \mathrm{~kg}$ \\
\hline Moti-ka-nagla & 1868 & Rajasthan, India & H6 & $1500 \mathrm{~g}$ \\
\hline Nedagolla & 1870 & Andhra Pradesh, India & Iron, ungrouped & $4.5 \mathrm{~kg}$ \\
\hline Dyalpur & 1872 & Uttar Pradesh, India & Ureilite & $300 \mathrm{~g}$ \\
\hline Nagaria & 1875 & Uttar Pradesh, India & Eucrite-cm & $20 \mathrm{~g}$ \\
\hline Sitathali & 1875 & Madhya Pradesh, India & H5 & $1600 \mathrm{~g}$ \\
\hline Judesegeri & 1876 & Karnataka, India & H6 & $680 \mathrm{~g}$ \\
\hline Bhagur & 1877 & Maharashtra, India & L6 & $18 \mathrm{~g}$ \\
\hline Dandapur & 1878 & Uttar Pradesh, India & L6 & $5.65 \mathrm{~kg}$ \\
\hline Haraiya & 1878 & Uttar Pradesh, India & Eucrite-mmict & $1000 \mathrm{~g}$ \\
\hline Kalumbi & 1879 & Maharashtra, India & L6 & $4.5 \mathrm{~kg}$ \\
\hline Andhara & 1880 & Bihar, India & Stone-unclassified & $2.7 \mathrm{~kg}$ \\
\hline Chetrinahatti & 1880 & Karnataka, India & Stone- unclassified & $72 \mathrm{~g}$ \\
\hline Pirthalla & 1884 & Haryana, India & H6 & $1161 \mathrm{~g}$ \\
\hline Chandpur & 1885 & Uttar Pradesh, India & L6 & $1100 \mathrm{~g}$ \\
\hline Nammianthal & 1886 & Tamil Nadu, India & H5 & $4.5 \mathrm{~kg}$ \\
\hline Lalitpur & 1887 & Uttar Pradesh, India & L6 & $372 \mathrm{~g}$ \\
\hline Kakangari & 1890 & Tamil Nadu, India & K3 & $350 \mathrm{~g}$ \\
\hline Nawapali & 1890 & Orissa, India & $\mathrm{CM} 2$ & $105 \mathrm{~g}$ \\
\hline Bansur & 1892 & Rajasthan, India & L6 & $15 \mathrm{~kg}$ \\
\hline Bherai & 1893 & Gujarat, India & L6 & $100 \mathrm{~g}$ \\
\hline Bori & 1894 & Madhya Pradesh, India & L6 & $8.6 \mathrm{~kg}$ \\
\hline Ambapur Nagla & 1895 & Uttar Pradesh, India & H5 & $6.4 \mathrm{~kg}$ \\
\hline Bishunpur & 1895 & Uttar Pradesh, India & LL3.15 & $1039 \mathrm{~g}$ \\
\hline Delhi & 1897 & Delhi, India & L5 & $0.8 \mathrm{~g}$ \\
\hline Kangra Valley & 1897 & Himachal Pradesh, India & H5 & $400 \mathrm{~g}$ \\
\hline Hyderabad & 1898 & Andhra Pradesh, India & Doubtful stone & -- \\
\hline Kodaikanal & 1898 & Tamil Nadu, India & Iron, IIE & $15.9 \mathrm{~kg}$ \\
\hline Donga Kohrod & 1899 & Madhya Pradesh, India & H6 & $230 \mathrm{~g}$ \\
\hline
\end{tabular}




\section{Continued}

\begin{tabular}{|c|c|c|c|c|}
\hline Alwal & 1901 & Andhra Pradesh, India & Doubtful Iron & -- \\
\hline Jemlapur & 1901 & India & L6 & $450 \mathrm{~g}$ \\
\hline Kamsagar & 1902 & Karnataka, India & L6 & $1293 \mathrm{~g}$ \\
\hline Bholghati & 1905 & Orissa, India & Howardite & $2.5 \mathrm{~kg}$ \\
\hline Vishnupur & 1906 & West Bengal, India & LL4-6 & $2.44 \mathrm{~kg}$ \\
\hline Chainpur & 1907 & Uttar Pradesh, India & LL3.4 & $8.2 \mathrm{~kg}$ \\
\hline Baroti & 1910 & Himachal Pradesh, India & L6 & $4.5 \mathrm{~kg}$ \\
\hline Khohar & 1910 & Madhya Pradesh, India & L3.6 & $9.7 \mathrm{~kg}$ \\
\hline Lakangaon & 1910 & Madhya Pradesh, India & Eucrite-mmict & $213 \mathrm{~g}$ \\
\hline Mirzapur & 1910 & Uttar Pradesh, India & L5 & $8.51 \mathrm{~kg}$ \\
\hline Tonk & 1911 & Rajasthan, India & CI1 & $7.7 \mathrm{~g}$ \\
\hline Shupiyan & 1912 & Jammu \& Kashmir, India & H6 & $5 \mathrm{~kg}$ \\
\hline Banswal & 1913 & Uttar Pradesh, India & L5 & $14 \mathrm{~g}$ \\
\hline Kuttippuram & 1914 & Kerala, India & L6 & $45 \mathrm{~kg}$ \\
\hline Ekh Khera & 1916 & Uttar Pradesh, India & H6 & $840 \mathrm{~g}$ \\
\hline Rampurhat & 1916 & West Bengal, India & LL & $100 \mathrm{~g}$ \\
\hline Sultanpur & 1916 & Uttar Pradesh, India & L/LL6 & $1711 \mathrm{~g}$ \\
\hline Cranganore & 1917 & Kerala, India & L6 & $1460 \mathrm{~g}$ \\
\hline Ranchapur & 1917 & Bihar, India & $\mathrm{H} 4$ & $290 \mathrm{~g}$ \\
\hline Atarra & 1920 & Uttar Pradesh, India & L4 & $1280 \mathrm{~g}$ \\
\hline Merua & 1920 & Uttar Pradesh, India & H5 & $71.4 \mathrm{~kg}$ \\
\hline Haripura & 1921 & Rajasthan, India & $\mathrm{CM} 2$ & $315 \mathrm{~g}$ \\
\hline Samelia & 1921 & Rajasthan, India & Iron, IIIAB & $2.46 \mathrm{~kg}$ \\
\hline Shikarpur & 1921 & Bihar, India & L6 & $3.68 \mathrm{~kg}$ \\
\hline Lua & 1926 & Rajasthan, India & L5 & $9.24 \mathrm{~kg}$ \\
\hline Naoki & 1928 & Maharashtra, India & $\mathrm{H} 6$ & $17 \mathrm{~kg}$ \\
\hline Rewari & 1929 & Haryana, India & L6 & $3.33 \mathrm{~kg}$ \\
\hline Khanpur & 1932 & Uttar Pradesh, India & LL5 & $3.7 \mathrm{~kg}$ \\
\hline Bahjoi & 1934 & Uttar Pradesh, India & Iron, IAB-sLL & $10.32 \mathrm{~kg}$ \\
\hline Tirupati & 1934 & Andhra Pradesh, India & H6 & $230 \mathrm{~g}$ \\
\hline Hyderabad & 1936 & Andhra Pradesh, India & Doubtful stone & -- \\
\hline Phulmari & 1936 & Maharashtra, India & Stone- unclassified & $4.06 \mathrm{~kg}$ \\
\hline Rangala & 1937 & Rajasthan, India & L6 & $3.22 \mathrm{~kg}$ \\
\hline Andura & 1939 & Maharashtra, India & H6 & $17.9 \mathrm{~kg}$ \\
\hline Erakot & 1940 & Madhya Pradesh, India & $\mathrm{CM} 2$ & $113 \mathrm{~g}$ \\
\hline Ramnagar & 1940 & Uttar Pradesh, India & L6 & $3.77 \mathrm{~kg}$ \\
\hline Semarkona & 1940 & Madhya Pradesh, India & LL3.00 & $691 \mathrm{~g}$ \\
\hline Kamalpur & 1942 & Uttar Pradesh, India & L6 & $2.77 \mathrm{~kg}$ \\
\hline
\end{tabular}




\section{Continued}

\begin{tabular}{|c|c|c|c|c|}
\hline Parsa & 1942 & Bihar, India & $\mathrm{EH} 3$ & $800 \mathrm{~g}$ \\
\hline Valdavur & 1944 & Pondicherry, India & H6 & $2.8 \mathrm{~kg}$ \\
\hline Sarratola & 1948 & Madhya Pradesh, India & L5 & $265 \mathrm{~g}$ \\
\hline Madhipura & 1950 & Bihar, India & $\mathrm{L}$ & $1000 \mathrm{~g}$ \\
\hline Lahrauli & 1955 & Uttar Pradesh, India & Ureilite & $900 \mathrm{~g}$ \\
\hline Soheria & 1960 & Bihar, India & OC & $72.9 \mathrm{~g}$ \\
\hline Desuri & 1962 & Rajasthan, India & H6 & $25.4 \mathrm{~kg}$ \\
\hline Muzaffarpur & 1964 & Bihar, India & Iron, IAB-sHL & $1245 \mathrm{~g}$ \\
\hline Seoni & 1966 & Maharashtra, India & H6 & $20 \mathrm{~kg}$ \\
\hline Patora & 1969 & Madhya Pradesh, India & H6 & $4.38 \mathrm{~kg}$ \\
\hline Dhajala & 1976 & Gujarat, India & $\mathrm{H} 3.8$ & $45 \mathrm{~kg}$ \\
\hline Udaipur & 1976 & India & $\mathrm{H} 3$ & $2 \mathrm{~kg}$ \\
\hline Nainital & 1980 & Uttar Pradesh, India & $\mathrm{L}$ & $5 \mathrm{~kg}$ \\
\hline Gujargaon & 1982 & Madhya Pradesh, India & H5 & $2.45 \mathrm{~kg}$ \\
\hline Ankhediya Mota & 1985 & Gujarat, India & $\mathrm{L} 4 / 5$ & $20 \mathrm{~kg}$ \\
\hline Kheri Maham & 1986 & Haryana, India & L5 & $68.5 \mathrm{~kg}$ \\
\hline Raghunathpura & 1986 & Rajasthan, India & Iron, IIAB & $10.2 \mathrm{~kg}$ \\
\hline Didwana & -- & Rajasthan, India & H5 & $1000 \mathrm{~g}$ \\
\hline Devri-Khera & 1994 & Madhya Pradesh, India & L6 & $1140 \mathrm{~g}$ \\
\hline Lohawat & 1994 & Rajasthan, India & Howardite & $40 \mathrm{~kg}$ \\
\hline Piplia Kalan & 1996 & Rajasthan, India & Eucrite-mmict & $42 \mathrm{~kg}$ \\
\hline Vissannapeta & 1997 & Andhra Pradesh, India & Eucrite-cm & $1304 \mathrm{~g}$ \\
\hline Sabrum $^{\star *}$ & 1999 & Tripura, India & LL6 & $478 \mathrm{~g}$ \\
\hline Itawa Bhopji & -- & Rajasthan, India & L3-5 & $1000 \mathrm{~g}$ \\
\hline Ararki & 2001 & Rajasthan, India & L5 & $4.46 \mathrm{~kg}$ \\
\hline Dergaon $^{* *}$ & 2001 & Assam, India & H5 & $12.5 \mathrm{~kg}$ \\
\hline Devgaon & 2001 & Madhya Pradesh, India & $\mathrm{H} 3.8$ & $12 \mathrm{~kg}$ \\
\hline Bhawad & 2002 & Rajasthan, India & LL6 & $678 \mathrm{~g}$ \\
\hline Kasauli & 2003 & Uttar Pradesh, India & $\mathrm{H} 4$ & $16.82 \mathrm{~kg}$ \\
\hline Kendrapara & 2003 & Orissa, India & $\mathrm{H} 4-5$ & $6.67 \mathrm{~kg}$ \\
\hline Kaprada & 2004 & Gujarat, India & L5/6 & $1600 \mathrm{~g}$ \\
\hline Jodiya & 2006 & Gujarat, India & L5 & $100 \mathrm{~g}$ \\
\hline Kavarpura & 2006 & Rajasthan, India & Iron, IIE-an & $6.8 \mathrm{~kg}$ \\
\hline Mahadevpur** & 2007 & Arunachal Pradesh, India & $\mathrm{H} 4 / 5$ & $70.5 \mathrm{~kg}$ \\
\hline Sulagiri & 2008 & Tamil Nadu, India & LL6 & $110 \mathrm{~kg}$ \\
\hline Katol & 2012 & Maharashtra, India & L6 & $13 \mathrm{~kg}$ \\
\hline Kamargaon $^{\star \star}$ & 2015 & Assam, India & L6 & $12.1 \mathrm{~kg}$ \\
\hline
\end{tabular}

** Meteorites fall/find in north-eastern India. 
Submit or recommend next manuscript to SCIRP and we will provide best service for you:

Accepting pre-submission inquiries through Email, Facebook, LinkedIn, Twitter, etc. A wide selection of journals (inclusive of 9 subjects, more than 200 journals)

Providing 24-hour high-quality service

User-friendly online submission system

Fair and swift peer-review system

Efficient typesetting and proofreading procedure

Display of the result of downloads and visits, as well as the number of cited articles Maximum dissemination of your research work

Submit your manuscript at: http://papersubmission.scirp.org/

Or contact gm@scirp.org 